\title{
Las conversiones religiosas en Granada en época moderna y contemporánea
}

Miguel Ángel Carvajal Contreras

Universidad de Granada (España) 



\title{
Las conversiones religiosas en Granada en época moderna y contemporánea
}

\section{Religious conversions in Granada in the Modern and Contemporary ages}

\author{
Miguel Ángel Carvajal Contreras \\ Universidad de Granada (España) \\ macarvajalcont@gmail.com
}

Fecha de recepción: 11 de diciembre de 2019

Fecha de aceptación: 26 de febrero de 2021

\section{Resumen}

El presente artículo trata de exponer el fenómeno de la diversidad religiosa en la ciudad de Granada, desde la conquista de la misma por los Reyes Católicos en 1492 hasta la actualidad, pasando por las diversas etapas históricas, mediante una perspectiva antropológica. Una vez producida la conquista definitiva, se lleva a cabo una progresiva cristianización de la capital y del Reino de Granada. La Granada post-renacentista, la de época barroca, presenta una población ya marcadamente cristianizada, aunque es aún destacable la labor inquisitorial. Este panorama se extiende a lo largo del siglo XVIII, cuando algunos viajeros extranjeros comienzan a visitar la ciudad, muchos de ellos de religión protestante, y ésta será también una constante en los viajeros del siglo XIX. Ya en el XX, especialmente a partir de la segunda mitad del siglo, será cuando se produzca una mayor llegada de religiones foráneas que resultarán atractivas para la conversión, esta vez ya no forzosa sino voluntaria, creando una imagen más plural de la ciudad.

Palabras clave: Conversión; Judeoconverso; Morisco; Pluralismo religioso; Granada (Reino). 


\begin{abstract}
This article deals with the fact of the religious diversity in the city of Granada, from its conquest by the Catholic King and Queen in 1492 up to now, and going through the different historical stages, with and anthropological perspective. Once Granada was definitely conquered, a progressive christianization of the city and its Kingdom was carried out. Post-renaissance Granada, in the baroque period, has population markedly christianized, although the inquisitorial work is still remarkable. This panorama extends all along the XVIII century, when some foreing travellers, many of them protestans, began to visit the city, as many of the travellers in the XIX century. In the XX century, specially in the second half, it will take place a greater arrival of foreign religions which will be attractive for people to convert to them. However, this time, it will not be a forced but a voluntary conversion, thus creating a more plural image of the city.
\end{abstract}

Keywords: Conversion; Judaeo-convert; Moorish; Religious pluralism; Granada (Kingdom).

\title{
1. INTRODUCGIÓN
}

El fenómeno de las conversiones, que podemos enmarcar dentro de lo que comúnmente denominamos como diversidad o pluralismo religioso, tan propio de las sociedades contemporáneas, hunde sin embargo sus raíces en épocas anteriores y se basa en la adopción por parte de una persona o de un grupo humano que antes era adepto a una antigua creencia ${ }^{1}$ de una nueva creencia, de una forma de entender el mundo y la conexión existente entre lo terrenal y lo espiritual, que procura asumir preceptos que antes no eran considerados por el converso por serle ajenos y su inmersión en la comunidad de creyentes en la que ingresa una vez ha abrazado su nueva fe.

La conversión, en cuanto a fenómeno social y cultural resulta considerablemente compleja, ya que se imbrican en ella diversos factores como la imposición de una religión y cultura sobre otra (conversiones que llamaremos forzosas) o la llegada de nuevos sistemas de valores a las sociedades actuales (conversiones que llamaremos voluntarias), así como factores más relacionados con el ámbito de los intereses económicos y políticos, y es una elección que puede darse tanto a nivel individual como a nivel grupal. En el caso individual, que en la actualidad es posiblemente el más frecuente, aunque no el único, y del que sin embargo ya en la Edad Media tenemos documentados algunos casos ${ }^{2}$, si bien muchas veces aislados, supondríamos que la persona en cuestión ha tenido un contacto con la nueva creencia que le ha resultado de agrado y por lo tanto ha decidido convertirse a la misma. En el caso grupal o colectivo las causas suelen ser más bien por imposición, dado que el hecho de cambiar de religión en lo que atañe a un grupo humano es algo como hemos señalado sumamente complejo (e, incluso podemos decir, doloroso), ya que queda minada una de

1 Bien siendo practicante de dicha creencia o simplemente socializado en la misma.

2 Algunos casos de judeoconversos en los Reinos de Castilla y Aragón en época previa a la expulsión de los judíos. Véase la obra Los judíos en Europa (Alianza Editorial, 2005). 
sus principales fuentes de identidad y cohesión social. Es más, una conversión como tal y en un sentido estricto del término conlleva no sólo el paso de una religión a otra sino de todo un sistema cultural; no es solamente la religión lo que se cambia sino todo lo que ella conlleva en relación a códigos socioculturales, pautas de comportamiento y cosmovisión en general. Toda conversión lleva, además, añadida, una suerte de ritual de paso que se puede manifestar desde el bautismo hasta la aceptación de preceptos delante de una comunidad de creyentes (Luckmann, 1999; Castilla, 2019).

En cuanto a la historia de los últimos cinco siglos en España, como veremos las conversiones han pasado de ser forzosas (comunidades de creyentes obligadas por ley a convertirse a una religión hegemónica, el catolicismo en este caso) a ser voluntarias, dentro de una renovación más tolerante de la legislación en cuanto a lo religioso y a la incursión en las últimas décadas de nuevas formas de entender la espiritualidad $\mathrm{y}$ de los denominados nuevos movimientos religiosos.

En el presente texto vamos a presentar el caso de una ciudad del sur de España, la ciudad de Granada, que sufrió en poco tiempo los avatares de pasar de ser la capital del último reino musulmán de la Península Ibérica a convertirse en una urbe fuertemente cristianizada, con un importante peso de las instituciones eclesiásticas ligadas al Tribunal del Santo Oficio de la Inquisición y con una población considerablemente heterogénea, donde se encontraban judeoconversos, moriscos y repobladores venidos del norte y de las más diversas zonas de la Península e incluso con habitantes provenientes de otros puntos del Mediterráneo occidental.

Una vez producida la rebelión de los moriscos de las Alpujarras y de otras zonas del Reino se realiza su expulsión y una nueva oleada de repobladores llega a los municipios cuya población había quedado mermada. Las poblaciones de origen judío y morisco se disipan, aparentemente, a partir de entonces debido a la "limpieza de sangre" y a la mezcla con otras poblaciones, y termina el período de conversiones forzosas de los siglos XV-XVI, aunque no la labor inquisitorial ligada al control del cumplimiento de la doctrina religiosa oficial y de los grupos que resultaban sospechosos. Durante el siglo XVII, la Contrarreforma proclama una espiritualidad barroca exultante, que tendrá eco en la religiosidad popular local y en la del sur de España en general. El siglo XVIII estaría marcado por la eclosión de las ideas ilustradas y la llegada de un racionalismo que casaba poco con la visión integrista de la Inquisición y del conservadurismo en cuanto a lo religioso y a su relación con el Estado $^{3}$. Los ilustrados españoles, si bien no dejan de ser del todo católicos creyentes y practicantes, plantean sin embargo un nuevo modo de concebir el país y las instituciones. Durante estos años los protestantes, anteriormente perseguidos y tachados de herejes, comienzan a llegar a España para hacer algunas observaciones sobre el país y sus gentes, si bien el tribunal inquisitorial sigue vigilando a los posibles simpatizantes con el protestantismo.

3 Este racionalismo estaría más extendido entre las clases letradas. 
De los ilustrados pasaremos, ya en el siglo XIX, a los viajeros románticos que, aunque en gran parte protestantes como sus predecesores, poseen una mirada menos racionalista que éstos y buscan en lo español reminiscencias de los musulmanes y de su cultura, realizando un retrato costumbrista y muchas veces orientalista del país (especialmente de Andalucía, y sobre todo de ciudades como Granada). Todo esto mientras en el terreno político nacional las ideas se mueven entre la defensa por un lado y la resistencia por otro de la separación total entre Iglesia y Estado, donde el conservadurismo y el liberalismo se contraponen como modelos ideológicos de concepción del país. Las conversiones durante este período son, sin embargo, escasas, y lo más destacable es la llegada de protestantes, especialmente británicos, que se establecen en las zonas de explotación minera y que traen consigo algunas de sus costumbres.

Por lo demás, no será hasta la segunda mitad del siglo XX cuando las conversiones comiencen a adquirir verdadera relevancia. Además de surgir algunas vertientes nuevas dentro del propio catolicismo como los neocatecumenales, comienzan a llegar otras provenientes del protestantismo (evangelistas, pentecostales), Testigos de Jehová, mormones, etc., si bien algunas de ellas ya las podemos encontrar desde el siglo XIX. En las últimas décadas es cuando el pluralismo religioso, amparado por el sistema legislativo, se expande de manera más clara y comienzan a producirse conversiones al Islam, al judaísmo ${ }^{4} \mathrm{o}$ al budismo, estableciéndose centros de culto como la mezquita de Granada o los centros budistas de la Alpujarra, centros culturales ligados a la cultura hebrea y musulmana y lugares para practicar ejercicios propios de las sabidurías y las espiritualidades orientales, como las artes marciales o el yoga ${ }^{5}$, entre otras.

\section{2. "CRISTIANOS VIEJOS" $\mathrm{Y}$ "CRISTIANOS NUEVOS": REPOBLADORES, JUDEOCONVERSOS Y MORISCOS EN GRANADA (1492 - 1610)}

El panorama ante el que nos encontramos en 1492 es el siguiente. Los Reyes Católicos conquistan la ciudad de Granada, hecho con el que finaliza la conquista del reino nazarí, y comienzan en la ciudad (que adquiere un significativo carácter simbólico relativo al triunfo cristiano) y en el Reino de Granada la que será una de sus principales empresas como monarcas: la definitiva cristianización ${ }^{6}$ del territorio peninsular y de la población acabada de conquistar, pese a las condiciones firmadas en las capitulaciones de entrega de la ciudad. En dichas capitulaciones se permitía

4 La recuperación de la memoria sefardí ha sido muy importante en cuanto al resurgir del judaísmo en España.

5 Estas prácticas no dejan de estar ligadas a las cosmovisiones de las culturas de las que son originarias.

6 En cuanto al control del territorio por parte de reyes cristianos. 
a la población musulmana mantener sus prácticas religiosas y culturales, lo cual no tardaría en incumplirse. Este mismo año se lleva a cabo el decreto de expulsión de los judíos que no se convirtieran al cristianismo ${ }^{7}$, los cuales se asentarían en diversos puntos de la cuenca del Mediterráneo (Norte de África, Balcanes, Oriente Próximo) y mantendrían a lo largo de los siglos la lengua y las canciones sefardíes, así como la añoranza por Sefarad. Lo mismo ocurriría, algo después, con los musulmanes y su añoranza por Al-Andalus. Estos sentimientos han pervivido en gran medida hasta la actualidad, transmitiéndose a lo largo de generaciones (González Alcantud y Rojo, 2015).

Los judeoconversos constituyen una parte de la población que, si ya existía en gran medida desde al menos un par de siglos antes (existe la conversión de judíos al catolicismo en los reinos cristianos peninsulares desde al menos el siglo XIII), se acrecienta con el decreto de expulsión firmado por los Reyes Católicos en Granada, el 31 de marzo de 1492 (Romero y Macías, 2004).

Algunos de ellos se convierten en religiosos de cierto prestigio que harán grandes alardes de su fe; se contraponen los que abrazan la nueva religión por imposición y con desgana, manteniendo en la medida de lo posible sus antiguas prácticas en secreto (criptojudíos) con los que, aun habiéndose convertido debido a dicha imposición, abrazan el catolicismo con entusiasmo y algunos con verdadero fervor, siendo cómplices de las observaciones religiosas hacia sus semejantes para que no realizasen prácticas judaizantes (Domínguez Ortiz, 1971).

El siglo XVI comenzará con la imposición de la religión y las costumbres cristianas a la población musulmana del Reino de Granada y la mudéjar del resto de los Reinos de Castilla y Aragón, pasando los musulmanes de mudéjares a moriscos (una vez ya cristianizados). Los moriscos constituyen una minoría étnica de considerable importancia, que conviven con la comunidad de "cristianos viejos" y de judeoconversos y que mantienen sus costumbres religiosas en la intimidad, ocultas a la vista de los demás y de las instituciones. Los judeoconversos se amoldarán más fácilmente a su nueva condición dentro de la sociedad, llegando a dar algunos nombres importantes a la espiritualidad y a las artes y las letras del Siglo de Oro. Los moriscos, sin embargo, se van a caracterizar por una resistencia a la aceptación completa de la cultura cristiana y por un considerable afán por conformar una comunidad aparte, bien diferenciada de la mayoritaria (Caro, 1986 [1962]). En el caso granadino, los moriscos constituyen una parte de la población más que considerable, que aparece representada comúnmente en los dibujos y grabados realizados por viajeros extranjeros sobre vistas de la ciudad (cabe destacar entre ellos los de Joris Hoefnagel). Estas representaciones dan cuenta de las vestimentas de los moriscos y las moriscas, así como de sus hijos, destacando las mujeres cubiertas con una larga saya que les cubría todo

7 Cabe destacar que en un principio los Reyes Católicos no tenían ningún especial problema con los judíos; fueron las presiones del ámbito eclesiástico y de sectores del poder las que finalmente decantaron la balanza a favor de la expulsión. 
el cuerpo. Los moriscos debían suponer algo exótico para los viajeros que venían de los países centroeuropeos, como Jerónimo Münzer, que los retratan y describen asombrados por sus atuendos y costumbres, en los años previos al punto álgido de la presión religiosa y cultural y la consiguiente rebelión. Los moriscos poseían conocimientos relativos al uso medicinal y mágico de plantas y hierbas, hecho por el cual fueron también acusados y juzgados por el tribunal inquisitorial (Caro, 1985 [1957]).

Cabe destacar, como primer arzobispo de Granada en 1493, la figura de Fray Hernando de Talavera, que sostuvo una política de conversión paulatina de la población autóctona pero sin usar la fuerza para ello, llegando a aprender árabe y predicando a los musulmanes granadinos en su propia lengua. Retrasaría incluso la llegada de la Inquisición a la ciudad, ya que recelaba de dicha institución, la cual lo investigaría por sus posibles orígenes judeoconversos. Sin embargo, en 1499 el Cardenal Cisneros le reprocha su actitud y exige que se empleen métodos más contundentes para la conversión, que ya será marcadamente forzosa, de los musulmanes, que pasan a convertirse en moriscos ${ }^{8}$. En 1500, Cisneros ordena la quema de libros musulmanes en la Plaza de Bib-Rambla. Este acto da muestra del rechazo que se produce hacia la sabiduría musulmana y de la animadversión de algunos sectores eclesiásticos hacia la cultura de los recién conquistados. A lo largo del siglo XVI vamos a encontrar también esta actitud de confrontación entre los religiosos tolerantes y los intolerantes con las creencias de la población autóctona en la conquista y catequización de América, así como en el trato hacia los propios nativos.

La creación de una otredad basada en la diferenciación étnica y religiosa resultaría sumamente beneficiosa no ya sólo para intereses de carácter religioso sino para la adquisición de los bienes requisados a los grupos, que una vez señalados pasan a ser considerados como marginales. Caerá sobre dichos grupos la permanente sospecha de su real conversión o si ésta es sólo fingida, y así actitudes como comer carne de cerdo o la asistencia frecuente a los oficios religiosos se convertirán en pruebas de una conversión sincera al cristianismo. En el caso granadino, cabe destacar además la conversión de algunas familias nobles nazaríes al cristianismo con la cual consiguen mantener su estatus dentro de la sociedad local una vez producida la conquista castellana. Este es el caso de los Granada-Venegas, Marqueses de Campotéjar y dueños de la Casa de los Tiros, edificio nobiliario de la capital granadina, en cuyo artesonado de la denominada Cuadra Dorada se representa a los nobles destacando su condición de cristianos, obviando sus orígenes. Algunos moriscos, que provienen de linajes destacados, lograrán con su conversión alcanzar puestos de relevancia en instituciones locales como los "Caballeros Veinticuatro" del cabildo granadino, caso de Hernando de Válor, líder de los moriscos alpujarreños al producirse el inicio de la rebelión de los mismos en 1568 con el nombre de Aben Humeya.

8 Para una referencia visual del proceso de conversión, pueden verse las tallas del retablo de la Capilla Real y del zócalo del altar mayor de la Catedral de Granada, donde se muestra el bautismo masivo de moriscos. 
Cabe destacar de la rebelión de los moriscos del Reino de Granada ${ }^{9}$ la insistencia que se hará en la represión (que dará lugar a episodios de carácter martirial) de los cristianos que no abjurasen de su fe, la profanación de templos y la destrucción de imágenes sagradas. Se pretendería con ello una vuelta de nuevo hacia la religión propia, desechando cualquier rastro que se pudiera ligar a la conversión y a la dominación ejercida por los cristianos hasta entonces. Claro está, esta actitud sería seguida especialmente por los grupos más integristas que por el común de la población morisca, pero las consecuencias de dichos actos recaerían sobre todos ellos una vez finalizado el conflicto en 1571 (Caro, 1985 [1957]).

Existe también en la visión de algunos moriscos rebelados un cierto profetismo islámico, tal y como señala González Alcantud (1997), siendo esta tendencia el reverso de aquel afán por demostrar orígenes cristianos en la población granadina debido a algunos conversos moriscos, lo que se había pretendido con el supuesto hallazgo de los denominados "libros plúmbeos" del Sacromonte ${ }^{10}$.

Una vez producida la conquista, comienzan a llegar a la ciudad y al resto del reino una gran cantidad de repobladores provenientes de diversas zonas de los reinos de Castilla, Navarra y Aragón, que se asientan en tierras que les son proporcionadas para su explotación y que contribuyen a la progresiva cristianización del territorio conquistado. Estos nuevos pobladores son conocidos como "cristianos viejos", para así diferenciarlos de los denominados "cristianos nuevos", es decir judeoconversos y moriscos, y señalar su antigüedad y "autenticidad" como cristianos de raigambre. Otros pobladores cristianos que llegan con fines en gran medida comerciales a la ciudad son los genoveses y algunos otros italianos, que se asentarán en la misma y elevarán edificios notables. Los repobladores llegarán nuevamente tras el fin de la rebelión ${ }^{11}$ de los moriscos de las Alpujarras (1568-1571), sublevación que se expande a otras partes del reino, y la expulsión de los mismos en 1610.

Es a partir de mediados del siglo XVI cuando la Inquisición comienza a adquirir un mayor protagonismo en la persecución de prácticas judaizantes y controlando a los moriscos, siendo los conversos vigilados para que mantuvieran los preceptos de su nueva religión. En los años previos a la rebelión de las Alpujarras y en los inme-

9 Aunque anteriormente hubo una revuelta en el barrio granadino del Albayzín, la rebelión de las Alpujarras sería el conflicto más importante y el que determinaría el futuro de los moriscos españoles.

10 Los libros plúmbeos hallados en el Sacromonte granadino (por lo que también reciben el nombre de plomos del Sacromonte), son una serie de planchas de plomo que se suponía contenían antiguos textos evangélicos en varias lenguas, y fueron halladas a finales del siglo XVI junto a algunos restos humanos que se suponía eran de mártires. Parece ser que fueron obra de unos moriscos granadinos que, una vez finalizada la rebelión, intentaron conciliar el cristianismo con el Islam a través de dichos documentos, demostrando que los árabes peninsulares habían sido inicialmente cristianos y que San Cecilio, patrón de Granada, lo era.

11 Los términos con los que se suele hacer referencia a este hecho histórico son rebelión, sublevación, levantamiento o guerra de las Alpujarras. 
diatamente posteriores a la misma el clima de tensión y los juicios irían en aumento, así como la vigilancia de dichas comunidades (García Ivars, 1991). El conflicto entre modos de entender la religiosidad, entre "dos civilizaciones" a fin de cuentas distintas, como afirma Bernard Vincent (1987), iba a verse rodeado de la persecución incesante de las prácticas culturales de los "otros", que aunque se suponía que se habían convertido no entraban en la estricta doctrina con la que se regía la vida española de la época, con una verdadera obsesión por la "pureza de sangre" que demostrara que no se tenían orígenes conversos. Esta obsesión por la pureza de sangre llegaría hasta la propia institución universitaria, siendo objeto de suma importancia para el control de los ingresados en la misma durante los siglos XVII y XVIII (Barrios Aguilera, 1982).

Una cuestión a destacar es que, pese a ser los moriscos una población ya cristianizada (en cuanto al recibimiento del bautismo, más que a la adopción de las prácticas religiosas y culturales que implica la conversión en sí), tras la rebelión de las Alpujarras una parte de los moriscos rebelados serán esclavizados por considerárseles traidores a la religión católica y por la situación en que los dejaba el hecho de ser prisioneros de guerra. Serán las mujeres especialmente las más esclavizadas, debido a su carácter de trabajadoras fuertes y afanosas y a los posibles intereses sexuales (Martín Casares, 1995, 1998).

Finalmente, una parte de la población de origen morisco permanecería hasta bien entrado el siglo XVIII en el Reino de Granada, integrada en la población y recuperada económicamente, con sus particularidades culturales (Soria, 2014).

Como último gran episodio de la persecución de los moriscos en el Reino de Granada, persecución cuya intensidad se iba alternando con la de la persecución de los judaizantes, hay que mencionar, ya en el siglo XVIII, el proceso inquisitorial llevado a cabo entre finales de 1727 y principios de 1728 en el que fueron acusadas varias familias de realizar prácticas mahometanas, aprovechando la ocasión para confiscar sus bienes (Caro, 1986 [1962]; García Ivars, 1991).

Una parte muy marginal de la población que provenía de un origen distinto eran los esclavos y esclavas negroafricanos, que provenientes la mayor parte de ellos de creencias animistas, acababan llevando una vida espiritual conformada por un sincretismo entre las formas religiosas que habían ido conociendo a lo largo de su vida, aunque en gran medida conservaran las prácticas animistas, si bien estas no eran consideradas por las autoridades religiosas como una forma de religión sino fruto de su ignorancia, por lo que no serían especialmente perseguidas como en el caso del judaísmo y el Islam. Algunos de estos esclavos habían sido islamizados previamente y por lo tanto se requirió su bautismo, ya que en este caso sí se veía la creencia como un problema que debía combatirse con la conversión (Martín Casares, 2000).

El grupo religioso que, dentro del cristianismo, iba a ser más perseguido por la Inquisición, serían los luteranos y demás formas de protestantismo, cuyos conversos se verían ante diversos autos de fe celebrados hasta los siglos XVII y XVIII. El tribu- 
nal inquisitorial de Granada muestra procesos a luteranos, calvinistas y hugonotes durante esta época (García Ivars, 1991).

En este caso, la hegemonía de la cosmovisión y la autoridad religiosa católica concebida como la verdadera, a juicio de los inquisidores, frente a la herejía del luteranismo, se enmarca dentro del punto de inflexión que dentro del cristianismo va a suponer la llegada de las tesis de Lutero, predicando una Iglesia menos pomposa y más austera, y la celebración del Concilio de Trento en el marco del combate de la denominada Reforma (protestante) y de la puesta en marcha de la Contrarreforma por parte de la Iglesia Católica, que estaba viendo amenazado su poder en el centro y norte de Europa, durante los reinados de Carlos V y Felipe II. Frente a la austeridad promulgada, el catolicismo respondería con la exaltación barroca de una religiosidad desbordada (heredada por algunas manifestaciones que han pervivido hasta la actualidad en la religiosidad que denominamos popular) y un sentido trágico-glorioso de entender la relación entre persona, colectivo y divinidad.

Cabe destacar también el hecho de identificarse lo español con lo católico, en una relación directa entre nacionalidad y credo. Esta idea del español como católico frente al extranjero hereje va a suponer una constante a lo largo de los siglos. Podemos observar, a modo de anécdota reveladora, la visión que sobre la idea que los españoles tenían acerca de los protestantes manifestó un escocés residente en la Alpujarra al hispanista inglés Gerald Brenan en la época en la que éste residió en dicha comarca (años 20-30 del siglo XX). Comenta lo siguiente:

"Hace doscientos años esta gente nos hubiera quemado a los dos [por ser protestantes]. Ahora todo lo que quieren es nuestro dinero." (Brenan, 2002 [1957], p. 162).

Como vemos, los tópicos sobre la mentalidad española de la época se mantenían entre algunos europeos hasta entonces.

\section{DEL BARROCO AL SIGLO DE LAS LUGES (1610 - 1799)}

Si el siglo XVI va a estar marcado por la presencia morisca y por la llegada de algunas ideas provenientes del protestantismo, el siglo XVII se va a caracterizar por la eclosión de la mentalidad barroca y sus manifestaciones artístico-culturales, dentro del marco de la Contrarreforma. Si bien las persecuciones a judeoconversos, moriscos y protestantes no cesan, sí tienen algunos momentos de relajación, en una época en la que el clima religioso está dominado por la visión piadosa y efectista del catolicismo, en las devociones marianas y relativas a los santos en una de sus mayores fases expresivas, asentando esta forma de entender lo religioso la forma no ya sólo en la que la propia institución eclesiástica va a tratar de empoderarse a partir de entonces sino la que las clases populares van a adoptar, a su manera, para expresar su religiosidad y su modo de relacionarse con lo sagrado. El arte barroco va a ser, en buena medida, propulsor de esta religiosidad (Gallego y Burín, 1987 [1956]). 
En el contexto de la exaltación de los principios religiosos y morales del catolicismo en la Europa occidental de la época, el propio Gallego y Burín (historiador y político granadino) expresa así la irrupción del arte barroco y su relación con la vida religiosa de los siglos XVII y XVIII:

"Es el momento agudo de la lucha contra las herejías, que marca un cambio en la espiritualidad, impone una severa disciplina eclesiástica, y rechaza toda interpretación religiosa individual, oponiendo a nuestro subjetivismo y a las anteriores exageraciones extáticas la actitud y la consideración del hecho humano de la Pasión." (Gallego y Burín, 1987 [1956]: 13).

Como vemos, el autor señala el carácter doctrinal de no permitir interpretaciones individuales del mensaje religioso (al contrario de lo que predicaba el luteranismo), sino que lo que se busca es la cohesión de los creyentes mediante una clara posición de poder de la institución eclesiástica, cuyas normas y preceptos debían ser acatados sin cuestionamiento, así como la visión exaltada del momento pasional y de los rituales y festividades ligadas a los santos patronos y santas patronas, véase cualquier paso de Semana Santa o fiesta patronal, con sus habituales despliegues de ostentosidad y la manifestación de la colectividad como una comunidad representada espiritualmente por la imagen en cuestión, a la que se hacen alabanzas y se canta, se reza y se hacen peticiones y promesas.

Los siglos XVII y XVIII se van a caracterizar en el caso de la ciudad de Granada por la aparición de nuevas formas organizativas ligadas a lo religioso, en especial de la fundamentación de devociones cuya implantación ya había surgido en el siglo anterior y de hermandades y cofradías vinculadas a las mismas.

Los cofradías, cuyo carácter asociativo crea la función cohesionadora de un determinado grupo social, van a cimentar la religiosidad promulgada desde los púlpitos a pie de calle; se organizan las procesiones y la devoción manifestada públicamente de las diversas imágenes y advocaciones marianas, de cristos y de santos y santas, mientras se potencia así la progresiva cristianización de la población "cristiana nueva”. Algunas de estas cofradías son de carácter étnico (las de negros esclavos, por ejemplo) o bien se corresponden con grupos provenientes de zonas geográficas distintas que se hallan conviviendo en la ciudad (cofradías grupales), que tenderán con el tiempo a identificarse con los barrios (Moreno, 1974). Este es el caso de la cofradía de Nuestra Señora de Covadonga, fundada en 1702 por asturianos y montañeses, que estuvo en activo durante todo el siglo XVIII y hasta la primera década del XIX (López-Guadalupe, 1990).

La época barroca está marcada por la celebración de multitud de procesiones y festejos religiosos, que dan muestra del afán por mostrar en público la religiosidad ${ }^{12}$

12 Hay que destacar las dos esferas en las que lo religioso puede manifestarse más claramente: la pública (con un habitual alarde de posibilidades estético-artísticas y de devoción grupal y cierta 
y también el triunfo del cristianismo en la ciudad, una vez asentado en la misma. Las manifestaciones pasionales, el mundo ligado a la celebración de la Semana Santa, es, sin embargo, el que va a ir sufriendo a lo largo del tiempo una mayor ambivalencia entre momentos de mayor y menor esplendor, debido en ocasiones a las posibilidades económicas de los miembros de las cofradías (Moreno, 1974; Briones, 1983; Rodríguez Becerra, 1999; López-Guadalupe y López-Guadalupe, 2002).

Durante el siglo XVII las conversiones siguen la misma tónica que en el siglo anterior: son escasas debido a las persecuciones de la Inquisición y a la mirada observadora de la institución eclesiástica y del entorno social. Los pocos que se convierten lo hacen habitualmente a alguna de las variantes del protestantismo, cuyas ideas llegan aunque no siempre muy fieles a los planteamientos originales, debido a la libre interpretación de los conversos y a la escasa información disponible y la dificultad de hallarla en la propia lengua, si bien encontramos en los procesos inquisitoriales información sobre algunos aspectos de estas nuevas creencias procedentes del luteranismo sobre todo, como el hecho de creer en la relación directa del ser humano con la divinidad sin necesidad de intermediarios (sacerdotes) y de no considerar el boato católico como necesario para el acercamiento a Dios (García Ivars, 1991).

El siglo XVIII va a suponer una verdadera revolución en cuanto al concepto de lo religioso y de las costumbres ligadas a las manifestaciones religiosas debido a la llegada de la Ilustración europea a España y la adopción de las ideas ilustradas por parte de los intelectuales y de algunos monarcas, especialmente Carlos III. Este siglo debemos considerarlo también en cuanto a la extensión del arte barroco (en ocasiones como en el caso de Granada hasta bien entrado el siglo) y la aparición, a finales del mismo, del neoclasicismo, mucho más del gusto de los ilustrados por ser un estilo considerado como más refinado y menos pomposo y exuberante. Como es comprensible, la explosión de la religiosidad va a verse afectada por una cierta sobriedad a finales del siglo, si bien la predilección de las clases populares será habitualmente más afín a la manifestación lo más vistosa posible de los elementos de la religiosidad. Existe aquí, por lo tanto, una dicotomía entre las clases poderosas ilustradas y las populares, ya que tienen preocupaciones, percepciones y anhelos en ocasiones distintos.

La visión de la Ilustración acerca de la religiosidad popular estaba marcada por la visión que los ilustrados tenían en sí de las reformas político-culturales que suponían necesitaba el país. En las reformas político-religiosas que se intentaron llevar a cabo, las ideas promulgadas por los monarcas y los políticos ilustrados tuvieron eco y fueron en gran cantidad de ocasiones secundadas por las autoridades eclesiásticas, que junto con las clases altas participaban también de esta religiosidad que era puesta en tela de juicio (véase como ejemplo fundamental de esto la propia Semana Santa) y formaban parte indispensable de la misma como organizadores de la vida y la norma

exaltación) y la privada, en algunos casos mucho más ligada a la creencia intimista, ya que se da en la intimidad y se corresponde con una identidad más personal que grupal en cuanto a la creencia religiosa. 
religiosa, aunque con sus intereses por el control y la vigilancia de la doctrina y de la práctica ceremonial o litúrgica.

Algo que molestaba especialmente a los ilustrados era que el pueblo dedicase sus esfuerzos y sus mayormente escasas posibilidades económicas en realzar una religiosidad demasiado pomposa a su juicio, donde los límites entre lo sagrado y lo profano eran muchas veces difusos y que estaba situada en el lado opuesto de la racionalidad que ellos defendían como nueva forma de entender las instituciones de todo tipo y las normas para regir el país, y por esto no es de extrañar que la forma en la que se llevaban a cabo los actos de festividad ligados a los religiosos, auspiciados además por sectores no especialmente gratos de la institución eclesiástica a los ilustrados (frailes, órdenes religiosas), fuera ampliamente criticada por los mismos (López-Guadalupe, 1994; López-Guadalupe y López-Guadalupe, 2002).

Las conversiones en el siglo XVIII siguen la misma tónica, son escasas y cuando se observa algún comportamiento sospechoso actúa el tribunal inquisitorial, si bien a lo largo del siglo irá aminorando su dureza anterior, también debido a que los grupos perseguidos ya no existían como tales (judeoconversos y moriscos estaban ya muy mezclados a esas alturas con el resto de la sociedad) y a la llegada de las ideas ilustradas, que veían la Inquisición como algo más propio del pasado. Se persiguen algunos casos de protestantismo a principios del siglo, además de los moriscos anteriormente mencionados, pero son escasos los autos de fe públicos.

Algo sin embargo a destacar es que comienzan a llegar al país algunos viajeros provenientes de países protestantes y siendo en ocasiones ellos mismos pastores protestantes. Esto es lo que ocurre, por ejemplo, con el reverendo Joseph Townsend, de ideas ilustradas, que realiza un viaje por España entre los años 1786 y 1787 y escribirá un libro sobre el mismo. Refleja en él algunas impresiones sobre Granada, especialmente sobre las instituciones presentes en la ciudad y las formas de religiosidad, donde nos muestra su visión sobre el catolicismo español de la época, resultando un documento de sumo interés.

\section{LIBERALES Y CONSERVADORES (1800 - 1900)}

El siglo XIX se va a caracterizar por el surgimiento de profundos cambios económicos, sociales y políticos en España, que van a afectar en cierta medida también a lo religioso. Una vez haya pasado la invasión napoleónica y la consecuente Guerra de la Independencia (1808-1814), el panorama del pensamiento político en el país se va a dirimir entre dos principales formas de entender lo que éste debe ser: surgen los liberales o progresistas y los moderados o conservadores. Estos dos modos de pensamiento poseen visiones distintas en cuanto a la relación entre la política y la religión y entre el propio Estado y la religión y sus instituciones. Unos defenderán las reformas constitucionales y otros se aferrarán, en un primer momento, al absolutismo. De esta defensa del absolutismo derivará la tendencia más reseñable dentro del ámbito 
político en cuanto al conservadurismo se refiere: el carlismo o tradicionalismo, que va a estar presente en el espectro político nacional con una cierta vigencia hasta la primera mitad del siglo XX, contando con una considerable fuerza en algunas zonas del país (sobre todo del noreste). Ésta ideología plantea una vuelta a las tradiciones más férreas y al catolicismo más tradicional, considerando al laicismo, tendencia que adoptarán algunos representantes políticos, como algo inaceptable para España. La defensa por un lado de la necesidad de separar y por otra de mantener unidos Estado e Iglesia van a ser una constante a lo largo del siglo, siendo más tendientes a una posición los liberales y a otra los conservadores, y en una posición más integrista los carlistas.

Un hecho a destacar por sus consecuencias para la institución eclesiástica son las desamortizaciones (expropiaciones de bienes a la Iglesia) por parte de Mendizábal y Madoz.

En cuanto a las conversiones, éstas no se dan apenas, dado que la población continúa siendo eminentemente católica practicante y no se suele contemplar la conversión a otro credo. Lo que sí encontramos es, en la tónica del siglo anterior, a diversos viajeros de origen protestante que viajan por el país. Sus obras nos dan muestra y constituyen un valioso testimonio de las costumbres y modos de vida de los territorios por los que pasan y sobre los que hacen sus observaciones, aunque con una mirada ligeramente distinta a la de sus predecesores. Esto se debe a que llegan cargados de ideas románticas sobre España y sus gentes, con todo un imaginario construido en base a los bandoleros, las mujeres seductoras, los gitanos, los "moros" y los elementos andalusíes, donde el pasado islámico y una visión un tanto goyesca del país se mezclan, con el orientalismo y el tipismo como ejes centrales. Esto es lo que se muestra en dibujos y grabados, e incluso en los inicios de la fotografía se viste a los habitantes locales con trajes considerados típicos y se los retrata con ellos puestos. Esta mezcla entre exotismo y costumbrismo se va a mantener durante todo el siglo XIX, hasta los inicios del XX, y sobre todo en Granada (Bernal Rodríguez, 1985; González Alcantud, 1988).

Pero más allá de la presencia de algunos viajeros de credo distinto, no encontramos como tal un número significativo ni de creyentes de otra religión distinta de la católica ni de conversos, ni aún en los lugares donde se establecen algunos señoricos de origen británico para llevar a cabo la explotación de recursos mineros o industriales.

El siglo XIX va a suponer el inicio inminente de la teoría de la denominada secularización, según la cual la religión iría teniendo cada vez menos peso en la vida de los ciudadanos, que irían siendo cada vez sujetos más racionales y desligados de sus antiguas creencias (Cantón, 2009; Weber, 2012 [1921]). Esta idea surge en el marco de una inicial ascendencia del cientificismo entre los pensadores, y en el fondo demuestra una extrapolación de la situación de un grupo social que podríamos considerar como hegemónico a los demás grupos sociales, como si necesariamente se 
tuvieran que comportar de una determinada forma porque los tiempos así lo "exigirían". Si bien los planteamientos weberianos de finales del siglo XIX y principios del $\mathrm{XX}$ resultan de gran interés para comprender la función social y el papel de la religión en las sociedades contemporáneas, la visión centroeuropea con la que el sociólogo trata el hecho de la secularización incipiente no se correspondía ni con las sociedades europeas meridionales de la época (ya se trate de católicas u ortodoxas), en las que el papel del campesinado seguiría siendo importante, ni con la situación que finalmente se ha venido dando, ya que no sólo no ha desaparecido completamente la religión de la vida cotidiana (bien es cierto que en el caso del catolicismo europeo éste puede haberse visto algo mermado en las últimas décadas pero sigue siendo aún de gran relevancia y las festividades muchas veces no se entienden sin el componente religioso al que van ligadas), sino que además ha ido surgiendo toda una amplia variedad de opciones religiosas a las que el individuo contemporáneo puede adscribirse. Esta situación, claro está, era poco imaginable en la época. La idea de la secularización, pero en el sentido de la necesidad de la misma para el avance del ser humano, va a ser prodigada por los pensadores e ideólogos del movimiento obrero, principalmente marxistas y anarquistas. Esta visión, sin embargo, tardará algunos años en calar en la mentalidad de la clase trabajadora en España, aunque una vez haya llegado va a marcar una visión dicotómica entre creencia y progreso, la cual no siempre se correspondía con la realidad ni siquiera con la cosmovisión de las clases denominadas como populares.

\section{TIEMPOS MODERNOS (1900-1959)}

La primera mitad del siglo XX se va a caracterizar en España por la convulsión política y la influencia que ésta va a tener en el terreno de la religión, especialmente una vez que los movimientos obreros se van a ir asentando entre amplios sectores de las clases populares. El país continúa siendo fundamentalmente católico, constituyendo la religión una de las principales características de la vida cotidiana, y así va a seguir siendo durante toda la primera mitad del siglo. Las conversiones siguen durante esta época sin ser especialmente numerosas. Lo más destacable son, en lo tocante al catolicismo, las actitudes surgidas durante la Segunda República (19311936), por un lado de anticlericalismo e iconoclastia y por otro de surgimiento de una reivindicación de la religión como síntoma de ser considerado un buen patriota. Esta visión dicotómica va a perdurar durante la década de los años 30 y va a ser fundamental durante la Guerra Civil (1936-1939), en la cual la alteridad entre creyente y no creyente va a alcanzar su máxima expresión en la España contemporánea (Delgado, 1992). Durante el transcurso de la guerra llegarán muchos marroquíes que combatirán junto a los sublevados, quienes permitirán la construcción de algunos lugares de culto y cementerios para ellos. En Granada, se levanta un cementerio situado junto al cementerio municipal, que ha sido recuperado por la comunidad musulmana actual de la ciudad para su uso. 
Una vez finalizada la contienda, con el triunfo del bando sublevado o franquista, se impone una visión férrea del catolicismo, que en una unión indivisible con el Estado va a denominarse nacionalcatolicismo. Se prodiga que ser un buen católico significa ser un buen español, volviendo a la vieja idea de la relación entre nacionalidad y credo. Los años más duros del nacionalcatolicismo serán los de la posguerra (1939-1952), si bien esta concepción político-religiosa va a marcar todo el régimen franquista hasta su fin en 1975. A partir de la década de los sesenta es cuando van a comenzar a aparecer algunos nuevos credos, aunque en un principio tímidamente, que se irán asentando a partir de los años setenta.

\section{LA LLEGADA DE NUEVOS CREDOS: PLURALISMO RELIGIOSO EN TIEMPOS GLOBALIZADOS (1959 HASTA LA ACTUALIDAD)}

La década de los sesenta va a suponer la llegada a España, una vez producido el inicio el aperturismo del régimen a algunas influencias del exterior, de ciertas nuevas ideas religiosas. Dentro del propio catolicismo, podemos destacar el surgimiento de los neocatecumenales en 1964, en un barrio de las afueras de Madrid. Se trata de una vertiente del catolicismo con prácticas que pueden considerarse herederas del cristianismo "primitivo", con celebraciones cercanas a las prácticas del judaísmo como forma de conexión con las ceremonias religiosas de las primeras comunidades cristianas. Así, la eucaristía, que suele durar unas dos horas o dos horas y media, se realiza no el domingo, sino el sábado por la noche, y se coloca un candelabro sobre la mesa (Castilla, 1999). Si los neocatecumenales van a hacer acto de presencia dentro del panorama de la religión predominante (el catolicismo) durante estos años, también van a irse visibilizando otras iglesias cristianas, algunas tan destacables como los Testigos de Jehová, que parten también de la idea de una vuelta al cristianismo más sencillo y primigenio, o la Iglesia de Jesucristo de los Santos de los Últimos Días (mormones), cuyas bases se fundamentan en la creencia de la estancia de Jesucristo en Norteamérica, la cual sería supuestamente demostrable a través de unas escrituras que fueron halladas por el fundador de este movimiento religioso en el siglo XIX. Estas creencias derivadas sobre todo del ámbito protestante van a ser vigiladas hasta los años del tardofranquismo, y a partir de 1975 se abre una nueva etapa que se va a caracterizar por la búsqueda de la libertad de pensamiento y de expresión.

En 1980, en plena transición democrática, se aprueba la Ley Orgánica de Libertad Religiosa, y en 1981 el Registro de Entidades Religiosas. El Estado pasa de ser confesional (en este caso ligado íntimamente al catolicismo como religión oficial estatal) a ser aconfesional, con pretensiones laicas. Aunque la religión predominante va a seguir siendo el catolicismo, con el que el Estado seguirá teniendo una relación especial, se irán estableciendo acuerdos con las distintas entidades religiosas presentes en el país para su colaboración con el Estado. Una de las variantes del protestantismo que llega y se hace importante es el evangelismo, especialmente con su 
variante pentecostal entre los gitanos (Cantón, 2004), que lo resignifican aportándole una condición de iglesia de carácter étnico (Iglesia de Filadelfia).

El fenómeno migratorio va a conllevar la llegada de musulmanes, judíos y protestantes, lo que ofrece un amplio panorama social y cultural de confesiones diversas que necesitan espacios de culto. En ocasiones, la necesidad de establecer dichos espacios se convierte en motivo de disputas con la población local y las instituciones, lográndose en algunos casos al final ciertos avances, como la construcción de la mezquita de Granada, en el barrio del Albayzín.

Las denominadas sabidurías orientales, ligadas al budismo, la meditación o el yoga, llegan en una suerte de amalgama New Age, que llena las paredes de anuncios y publicidad sobre centros para desarrollar estas actividades cercanas a nuevas formas (nuevas en el ámbito occidental), de espiritualidad y filosofías de vida. Dentro de estos movimientos podríamos incluir el neochamanismo y las formas actuales de misticismo (Prat, 2017).

En el ambiente de esta diversidad o pluralismo religioso, el fenómeno de las conversiones se ha convertido en una parte fundamental debido a su creciente auge en las últimas décadas, auspiciado por dos cuestiones principales: la religión tradicional (pongamos en nuestro caso el catolicismo) pierde en parte su antigua omnipresencia y queda ligada más a la celebración de eventos vistosos (Semana Santa, Corpus, etc.) que a la vida religiosa individual e intimista, y dada la libertad que se establece legalmente para la conversión, ya no forzosa sino plenamente voluntaria, se descubren y adoptan nuevas creencias en el marco del que se ha denominado "mercado religioso" (Vallverdú, 2001). Existe variedad donde elegir, pero también nuevas formas de resignificar las antiguas creencias (catolicismo "a la carta", sin hacer demasiado caso de las indicaciones de las autoridades eclasiásticas). Las conversiones al Islam, al judaísmo como forma de recuperación de la memoria sefardí, al budismo o a las variantes del protestantismo no dejan de ser el producto de una sociedad globalizada, donde los aspectos de los más diversos entornos socioculturales se encuentran y se funden, se sincretizan y crean comunidades religiosas donde antes no existían o no eran especialmente numerosas (Díez de Velasco, 2014; Castilla, 2019).

El fenómeno del pluralismo religioso ha conllevado una amplia labor de investigación para comprender cómo las diversas confesiones coexisten en el espacio urbano y en las diversas comunidades autónomas (Briones, 2010; Salguero, 2010). El Observatorio del Pluralismo Religioso, así como la Fundación Pluralismo y Convivencia, a la que está vinculado, se han encargado de promover estudios sobre la situación del pluralismo religioso en la sociedad española actual. En el Registro de Entidades Religiosas podemos encontrar las diversas confesiones que han sido registradas oficialmente, y el Observatorio Andalusí y la Encuesta de Opinión Activa se han encargado de indagar sobre la visión acerca de dicho fenómeno, en el caso de religiones como la islámica con especial atención dada la relevancia de su presencia. Las conversiones han ampliado la dimensión del fenómeno de la pluralidad religiosa, 
siendo destacables en el caso granadino los ejemplos del Islam, contando la capital con una mezquita y un cementerio musulmán, que son sostenidos en gran medida por el sector converso de la comunidad musulmana local; las iglesias cristianas distintas del catolicismo, como los Testigos de Jehová y los mormones, que cuentan con centros de culto situados en barrios a las afueras de la ciudad, así como las iglesias étnicas, especialmente del ámbito del pentecostalismo; el budismo y, en menor medida, el judaísmo, que cuenta con algunos espacios museísticos en los barrios históricos de la ciudad en los que se rememora el legado sefardí.

\section{REFLEXIONES FINALES}

Como hemos visto, las conversiones suponen un hecho ligado al encuentro entre culturas, al deseo de pertenecer o de hacer pertenecer al otro a una determinada cultura, donde las posturas pueden oscilar entre la consideración de la imposición del modelo religioso como defensa de la conversión (forzosa en este caso), y la consideración de hacer llegar el mensaje religioso para la conversión de manera libre (conversiones voluntarias). A lo largo de los siglos, los pueblos han intentado o bien obligarse entre sí a adoptar una religión y una cultura nuevas, o bien procurar la suficiente dosis de proselitismo para hacer la conversión posible. Las conversiones suponen un campo en el que la disciplina antropológica, apoyada con una perspectiva temporal (histórica), puede aportar explicaciones e interpretar esta realidad social y cultural que no habíamos tenido en cuenta hasta fechas recientes. La conversión es un hecho tan importante en la vida del individuo o del grupo que adopta una nueva religión que no sólo conlleva la mera adopción de esa religión sino de toda una serie de preceptos y comportamientos culturales que antes le eran ajenos, y que van a marcar su vida cotidiana a partir de ese momento.

La ciudad de Granada, con un gran impacto de la diversidad cultural actual, supone un lugar excepcional para analizar este fenómeno, y para ello podemos partir del conocimiento acerca de la relación que el propio territorio ha tenido previamente con las conversiones. Si hace cinco siglos la norma era la conversión por decreto y forzosa, ante la que se mostraban fuertes resistencias, en la actualidad la conversión ha pasado a ser un acto voluntario, en el que la libertad individual se desliga de la obligación de pertenecer a un grupo para poder tomar las decisiones que se consideren convenientes acerca de la propia espiritualidad, si bien al final se acabará perteneciendo a otro nuevo grupo. A pesar del individualismo, el ser humano no deja de ser que vive y necesita vivir en sociedad.

La religión acaba por lo tanto definiendo y sirviendo de fuente de identidad a individuo y a grupo, a comunidad, ante el resto de los creyentes y de los miembros laicos de la sociedad. No deja la religión de seguir cumpliendo dos de sus objetivos más antiguos, dotar al ser humano de la capacidad de interactuar con lo divino y de servirle como modo de cohesión. 


\section{BIBLIOGRAFÍA}

Álvarez Santaló, León Carlos (1997). La fiesta religiosa barroca y la ciudad mental. En Sánchez Ramos, Valeriano y Ruiz Fernández, José (coord.). Actas de las Ia jornadas de Religiosidad Popular: Almería, 1996. Almería: Instituto de Estudios Almerienses, pp. 13-28.

Barrios Aguilera, Manuel y Sánchez Ramos, Valeriano (1997). El legado martirial en la estructuración de la sociedad repobladora de las Alpujarras. En Sánchez Ramos, Valeriano y Ruiz Fernández, José (coord.). Actas de las I ${ }^{a}$ Jornadas de Religiosidad Popular: Almería, 1996. Almería: Instituto de Estudios Almerienses, pp. 121-144.

Barrios Aguilera, Manuel (1982). Graduación y 'limpieza de sangre’ en la Universidad de Granada, 1663-1788. Materiales para su estudio. Chronica Nova, n. 13, pp. 53-102. DOI: https://doi.org/10.30827/cn.v0i0.2894

Barrios Aguilera, Manuel (1984). Alfacar morisco: (un lugar en la Vega de Granada en el siglo XVI). Granada: Universidad de Granada.

Barrios Aguilera, Manuel (1985). Contribución al estudio de la repoblación de la Vega de Granada tras la expulsión de los moriscos: El caso de Güevéjar. Chronica Nova, n.14, pp. 7-46. DOI: https://doi.org/10.30827/cn.v0i0.2882

Barrios Aguilera, Manuel (2004). El Sacromonte de Granada y la religiosidad contrarreformista. En Sánchez Ramos, Valeriano y Ruiz Fernández, José (coord.). La Religiosidad popular y Almería: actas de las III Jornadas. Almería: Instituto de Estudios Almerienses, pp. 15-37.

Bernal Rodríguez, Manuel (1985). La Andalucía de los libros de viajes del siglo XIX. Sevilla: Editoriales Andaluzas Unidas.

Brenan, Gerald (2002) [1957]. Al Sur de Granada. Barcelona: Tusquets.

Briones Gómez, Rafael (1983). La Semana Santa andaluza. Gazeta de Antropología [en línea], núm. 2, texto 2-1. Disponible en: http://www.gazeta-antropologia.es/?p=3920

Briones Gómez, Rafael (1993). La experiencia simbólica de la Semana Santa: funcionamiento y utilidad. Gazeta de Antropología [en línea], núm. 10, texto 10-7. Disponible en: http://www.gazeta-antropologia.es/?p=3639

Briones Gómez, Rafael (1995). Aproximación antropológica a tres casos de religiosidad marginal en la provincia de Granada. Gazeta de Antropología [en línea], núm. 11, text 11-9. Disponible en: http://www.gazeta-antropologia.es/?p=3600

Briones Gómez, Rafael (1997). Catolicismo popular y esfera de lo privado. El impacto del catolicismo popular en la esfera privada, en la Andalucía contemporánea. En Sánchez Ramos, Valeriano y Ruiz Fernández, José (coord.). Actas de las $I^{a}$ Jornadas de Religiosidad Popular: Almería, 1996. Almería: Instituto de Estudios Almerienses, pp. 31-49.

Briones Gómez, Rafael (coord.). (2010). ¿T tú (de) quién eres? Minorías religiosas en Andalucía. Barcelona: Icaria. 
Buxó Rey, María Jesús, Rodríguez Becerra, Salvador y Álvarez y Santaló, León Carlos (coord). (1989). La religiosidad popular. Barcelona: Anthropos.

Cantón Delgado, Manuela y Gil Tébar, Pilar (2011). Políticas, resistencias y diásporas religiosas en perspectiva transcultural: gitanos evangélicos en España e indígenas católicos en México. Revista de Antropología Social, n. 20, pp. 77-108. DOI: https:// doi.org/10.5209/rev_RASO.2011.v20.36263

Cantón Delgado, Manuela (coord.). (2004). Gitanos pentecostales. Una mirada antropológica a la Iglesia Filadelfia en Andalucía. Sevilla: Signatura Ediciones de Andalucía.

Cantón Delgado, Manuela (2008). Los confines de la impostura. Reflexiones sobre el trabajo etnográfico entre minorías religiosas. Revista de Dialectología y Tradiciones Populares, n. 63-1, pp. 147-172. DOI: https://doi.org/10.3989/rdtp.2008.v63.i1.50

Cantón Delgado, Manuela (2009). La razón hechizada: teorías antropológicas de la religión. Barcelona: Ariel.

Cantón Delgado, Manuela (2013). Etnopolíticas del evangelismo gitano y esfera pública. Transversalidad, poder, etnicidad. Política y sociedad, Vol. 50, n. 3, pp. 1037-1063. DOI: https://doi.org/10.5209/rev_POSO.2013.v50.n3.40757

Caro Baroja, Julio (1978). Las formas complejas de la vida religiosa (Siglos XVI y XVII). Madrid: Akal.

Caro Baroja, Julio (1985) [1957]. Los moriscos del Reino de Granada. Madrid: Istmo.

Caro Baroja, Julio (1986) [1962]. Los judíos en la España Moderna y Contemporánea. Madrid: Istmo.

Caro Baroja, Julio (2006) [1968]. El señor inquisidor y otras vidas por oficio. Madrid: Alianza Editorial.

Carrasco Urgoiti, Soledad y Martínez Ruiz, Juan (1989). El moro de Granada en la literatura: (del siglo XV al XIX). Granada: Universidad de Granada.

Carrasco Urgoiti, Soledad (1996). El moro retador y el moro amigo (estudios sobre fiestas y comedias de moros y cristianos). Granada: Universidad de Granada.

Cascales Ramos, Antonio (1986). La Inquisición en Andalucía. Resistencia de los conversos a su implantación. Sevilla: Editoriales Andaluzas Unidas.

Castilla Vázquez, Carmen (1999). De neófitos a iniciados: el movimiento neocatecumenal y sus ritos de admisión. Gazeta de Antropología [en línea], núm. 15, texto 15-4. Disponible en: http://www.gazeta-antropologia.es/?p=3443

Castilla Vázquez, Carmen (2015). Del desinterés al entusiasmo: El fenómeno religioso en la investigación etnográfica española. Gazeta de Antropología [en línea], núm. 31, 2, texto 31-1. Disponible en: http://www.gazeta-antropologia.es/?p=4719

Castilla Vázquez, Carmen (2019). La conversión religiosa como instrumento de búsqueda y creación de identidades: el budismo tibetano en España. Revista de Humanidades, n. 38, pp. 161-180. DOI: https://doi.org/10.5944/rdh.38.2019.25533 
Castón Boyer, Pedro (coord.). (1985). La religión en Andalucía (aproximación a la religiosidad popular). Sevilla: Editoriales Andaluzas Unidas.

Christian, William (1991) Religiosidad local en la España de Felipe II. San Sebastián: Nerea,

Delgado Ruiz, Manuel (1992). La ira sagrada: anticlericalismo, iconoclastia y antirritualismo en la España contemporánea. Barcelona: Humanidades.

Díez de Velasco, Francisco (2014). Breve historia de las religiones. Madrid: Alianza Editorial.

Domínguez Ortiz, Antonio (1971). Losjudeoconversos en España y América. Madrid: Istmo.

Fernández Campos, Gabino (1986). Reforma y Contrarreforma en Andalucía. Sevilla: Editoriales Andaluzas Unidas.

Gallego y Burín, Antonio (1987) [1956]. El barroco granadino. Granada: Comares.

García Ivars, Flora (1991). La represión en el tribunal inquisitorial de Granada. 1550 1819. Madrid: Akal.

Gómez García, Pedro (1991). Religión popular y mesianismo. Análisis de cultura andalu$z a$. Granada: Universidad de Granada.

González Alcantud, José Antonio (1988). Teoría del exotismo. Gazeta de Antropología [en línea], núm. 6, texto 6-2. Disponible en: http://www.gazeta-antropologia. $\mathrm{es} / \mathrm{p}=3787$

González Alcantud, José Antonio (1997). El profetismo y la imposibilidad del milenarismo en la rebelión morisca de 1568. Anales de la Fundación Joaquín Costa, n. 14, pp. 201-216.

González Alcantud, José Antonio y Rojo Flores, Sandra (2015). Andalusíes. Antropología e historia cultural de una élite magrebí. Madrid: Abada.

López-Guadalupe Muñoz, Miguel Luis (1990). La Hermandad de Ntra. Sra. de Covadonga, de asturianos y montañeses, de Granada (1702-1810). Chronica Nova, n. 18, pp. 237-266. DOI: https://doi.org/10.30827/cn.v0i18.2816

López-Guadalupe Muñoz, Miguel Luis (1994). La fiesta religiosa en la diócesis de Granada (1750-1825). Opinión, control y represión. Chronica Nova, n. 21, pp. 239-278. DOI: https://doi.org/10.30827/cn.v0i21.2726

López-Guadalupe Muñoz, Miguel Luis (1995). Las cofradías de penitencia de Granada en la Edad Moderna. Gazeta de Antropología [en línea], núm. 11, texto 11-12. Disponible en: http://www.gazeta-antropologia.es/?p=3607

López-Guadalupe Muñoz, Miguel Luis y López-Guadalupe Muñoz, Juan Jesús (2002). Historia viva de la Semana Santa de Granada. Arte y devoción. Granada: Universidad de Granada.

Luckmann, Thomas (1999). The Religious Situation in Europe: the Background to Contemporary Conversions. Social Compass, n. 46 (3), pp. 251-258. DOI: https://doi. org/10.1177\%2F003776899046003002 
Martín Casares, Aurelia (1995). De la esclavitud a la libertad: las voces de las moriscos y moriscos en la Granada del siglo XVI. Sharq Al-Andalus: Estudios mudéjares y moriscos, n. 12, pp. 197-212.

Martín Casares, Aurelia (1998). Esclavitud y mentalidad: la población esclava de Granada a lo largo del siglo XVI. Chronica Nova, n. 25, pp. 337-348. DOI: https://doi. org/10.30827/cn.v0i25.2077

Martín Casares, Aurelia (2000). La esclavitud en Granada en el siglo XVI. Género, raza y religión. Granada: Universidad de Granada.

Martín Casares, Aurelia (coord.). (2014). Esclavitudes hispánicas (siglos XV al XXI: horizontes socioculturales). Granada: Universidad de Granada.

Moreno Navarro, Isidoro (1974). Las hermandades andaluzas. Una aproximación desde la Antropología. Sevilla: Universidad de Sevilla.

Moreno Navarro, Isidoro (1997). Los rituales festivos religiosos andaluces en la contemporaneidad. En Sánchez Ramos, Valeriano y Ruiz Fernández, José (coord.). Actas de las Ia jornadas de Religiosidad Popular: Almería, 1996. Almería: Instituto de Estudios Almerienses, pp. 319-332.

Pérez-Agote, Alfonso (2012). Cambio religioso en España: los avatares de la secularización. Madrid: CIS.

Prat Carós, Joan (2001). El estigma del extraño: un ensayo antropológico sobre sectas religiosas. Barcelona: Ariel.

Prat Carós, Joan (2017). La nostalgia de los orígenes. Chamanes, gnósticos, monjes y místicos. Barcelona: Kairós.

Rodríguez Becerra, Salvador (coord.). (1999). Religión y cultura. Sevilla: Junta de Andalucía.

Romero Castelló, Elena y Macías Kapón, Uriel (2005). Los judíos en Europa. Madrid: Alianza Editorial.

Salguero Montaño, Óscar (2010). Necesidades de las comunidades religiosas en Andalucía. En R. Briones Gómez (coord.). ¿T tú (de) quién eres?: minorías religiosas en Andalucía. Barcelona: Icaria, pp. 483-492.

Soria Mesa, Enrique (2014). Los últimos moriscos: pervivencias de la población de origen islámico en el reino de Granada (siglos XVII-XVIII). Valencia: Universitat de València, Universidad de Granada y Universidad de Zaragoza.

Vallverdú Vallverdú, Jaume (2001). Mercado religioso y movimientos carismáticos en la modernidad. Gazeta de Antropología [en línea], núm. 17, texto 17-22. Disponible en: http://www.gazeta-antropologia.es/?p=3282

Vallverdú Vallverdú, Jaume (2016). Tecnología y religión: diseño teórico de una investigación en curso. Arxius de sociologia, n. 34, pp. 169-183.

Vincent, Bernard (1982). Los moriscos y la Inquisición (1563-1571). Chronica Nova, $\mathrm{n}$. 13, pp. 197-205. DOI: https://doi.org/10.30827/cn.v0i0.2901 
Vincent, Bernard (1987). Minorías y marginados en la España del siglo XVI. Granada: Diputación Provincial de Granada.

Vincent, Bernard (1998). La repoblación del Reino de Granada: espacios y tiempos. Chronica Nova, n. 25, pp. 111-137. DOI: https://doi.org/10.30827/cn.v0i25.2068

Weber, Max (2012) [1921]. Sociología de la religión. Madrid: Akal. 